\title{
Correlation between Magnetic Resonance Imaging and Arthroscopy in Meniscal Injuries
}

\author{
Andrés Gelink ${ }^{1 *}$, Nicolás Casales ${ }^{1}$, Nora Macadar ${ }^{2}$, Luis Francescoli ${ }^{1}$ \\ ${ }^{1}$ University Clinic of Traumatology and Orthopaedics, UDELAR, INOT, Montevideo, Uruguay \\ ${ }^{2}$ Center for Imagenology CCOU, SMI, Montevideo, Uruguay
}

${ }^{*}$ Corresponding author: Andrés Gelink, University Clinic of Traumatology and Orthopaedics, UDELAR, INOT, Montevideo, Uruguay; E-mail: agelink10@hotmail.com

Received: July 03 2019; Accepted: July 16, 2019; Published: July 18, 2019;

\begin{abstract}
Introduction: Meniscal injuries have a very high incidence among professional and amateur athletes. It is estimated that the incidence amounts to 24 every 100000 each year. The different forms of imaging diagnostics play an important role in the management of knee injuries, particularly in the event of uncertain clinical diagnosis, helping to avoid unnecessary and expensive surgeries. In order to diagnose meniscal pathologies, the most commonly used imaging test is Magnetic Resonance Imaging (MRI). Health Officials from all around the world are becoming increasingly involved in the definition of surgical treatment limits, making an effort to enhance their practice and the patients' cost-effectiveness.
\end{abstract}

Our work aims to review evidence about the correspondence between imaging tests -particularly the MRI- and knee arthroscopy as the Gold Standard for the diagnosis of meniscal injuries.

Material and Methods: We performed a systematic search that included Medline (PubMed interphase) and Lilacs databases. The search totaled 607 articles. According to filters and inclusion/exclusion criteria, 23 papers were chosen for our bibliographic review.

Results: The selected papers were prospective studies. Our results are based on data retrieval specifically linked to sensitivity and specificity of the MRI with regards to arthroscopy in meniscal injuries.

Discussion: From the analysis of this information we may consider that there is no consistency in results and opinions in English-published bibliography of a prospective profile. Nevertheless, we must acknowledge that the prevailing results are those that prioritize the relevance of MRI in terms of sensitivity and specificity. We must currently accept that MRI is a very costly study for diagnosing meniscal injuries. There are some variations in its sensitivity and specificity, but they are minor and, therefore, do not invalidate these conclusions.

\section{Introduction}

Meniscal injuries have a very high incidence among professional and amateur athletes. This injury is one of the most frequent in sports medicine: 24 in every 100000 athletes suffer one of this each year. They show a bimodal distribution; the first incidence peak is seen among young athletes and the second is seen in middle-aged patients with degenerative joint disease [1].

Macroscopically, the menisci of the knee are two intra-articular semicircular fibrocartilaginous structure, with a wedge shaped structure, placed between the tibia and the femur, in the medial and lateral compartments. They used to be considered as vestigial remains of muscular structures in the knee. Ever since the middle of the Twentieth Century we have thoroughly known their actual functions and their anatomic, therapeutic and prognostic relevance in knee pathology. The menisci have three main functions: load transmission, cushioning and secondary stabilization [2-4].

In general, the medial meniscus is the one with less movement and therefore it gets injured more frequently than the lateral meniscus [5].

In terms of clinical diagnosis, there are over twenty specific tests described for the assessment of meniscal injuries, with sensitivity and specificity levels that fall between 64 and 97\% [6-10]. The sensitivity of these tests decreases when there are other associated injuries, particularly of the anterior cruciate ligament [11-13].

The different forms of imaging diagnostic play an important role in the management of knee injuries, and particularly in the event of uncertain clinical diagnosis; they help to avoid unnecessary surgeries [14].

Since MRI was first introduced in 1984 for clinical usage, its diagnostic role in knee injuries has had a substantial impact [15-17]. MRI is the most commonly used imaging study for the diagnosis of meniscal pathologies, even though there has been an increasing amount of studies that conclude that ultrasonography might be a valid diagnostic technique for meniscal injuries [18]. Notwithstanding, MRI possesses one advantage: it assesses both hard and strong parts of the knee together with the meniscal pathology

Some studies have shown that MRI is not better than physical examination for diagnosis of meniscal injuries $[7,8,19]$; other studies show that diagnostic failures range between 14 and 47\% [20-22] and others showed the value of MRI as an effective and non-invasive diagnostic tool [11,23-30]. 
MRI and ultrasonography are the two most used screening methods for diagnosing meniscal tears and anterior cruciate ligament (ACL) tears. While there are numerous studies that show that MRI is a reliable and accurate diagnostic tool, it is very hard to establish its true sensitivity and specificity [29]. Ruwe et.al [31]. claim that MRI avoids unnecessary arthroscopies, while Bridgman et.al [32] State it doesn't.

Currrently we need the highest levels of evidence in order to support the use of diagnostic tests, especially when these are an important part of the definition of therapeutic limits, such as knee arthroscopy, for anterior cruciate ligament and meniscus injuries. In the future, the technological and clinical advances shall, undoubtedly, change the way we use MRI [33].

\section{Objective}

This paper aims to review evidence about the correlation between MRI and knee arthroscopy as the Gold Standard for the diagnosis of meniscal injuries.

\section{Material and Methods}

In May 2018, we performed a systematic search that included Medline (PubMed interphase) and Lilacs databases. We used similar search methods in both databases, employing the term MESH for Medline-PubMed.

We combined the results using Boolean operators; the synthetic results for said search were (("Menisci, Tibial" [Mesh]) AND "Magnetic Resonance Imaging”[Mesh]) AND “Arthroscopy”[Mesh].

In Lilacs we applied the same search method.

The filters we used were articles published between 2004 and 2018, articles written in English and articles about human beings.

\section{Inclusion Criteria}

The inclusion criteria were:

- Human, adults, and published in English.

- Prospective cohort studies

- Evaluation of MRI for the diagnosis of meniscal injuries

- Arthroscopy as a diagnostic reference (Gold Standard)

- Results with sensitivity and specificity (Se.\& Sp.)

\section{Exclusion Criteria}

Exclusion criteria were: retrospective articles, systematic reviews, children injuries, kinds of meniscal injuries.

Thereafter, we selected the title, made an overview (or full review in case of doubts) and used each work's bibliography as an additional method.

Even though there are differences among the meniscal injury diagnosis criteria in MRIs, it is widely accepted that the presence of an intra-meniscal signal extending to an articular surface and/or a distortion of the regular shape represent a clinically significant injury [34].

\section{Search Strategies}

For the bibliographic selection we used, as a guide, the flow chart from the PRISMA (Preferred Reporting Items for Systematic Review and Meta-Analysis) protocols (Figure 1).

In Medline-PubMed we obtained 593 results as a total, using MESH terms and Boolean operators. After applying the aforementioned filters, the results were the following:

- Since 2004 to 2018: 396

- In humans: 390

- In English: 360

In the Lilacs platform we found 14 studies, and applying the same filters we found 3 papers, one of which also turned up in the MedlinePubMed search.

From both searches, and excluding the repeated article, we obtained 362 articles that, added to 6 other papers found in the bibliography, gave us a total of 368 studies.

When we applied the aforementioned inclusion and exclusion criteria in both platforms with regards to title and overview, we selected 23 articles in total (this excluded 345 studies); so far the search was conducted by only one author.

Afterwards, these 23 studies were read in full and included in our bibliographic review by 2 authors.

When applicable, we extracted the following data from each work: Author, Year of Publishing, Hospital, Study Design, Amount of Patients, Patients' Age, Study Period, 1 or both menisci studied, Se. \& Sp. (Table 1).

\section{Results}

All 23 articles were diagnostic prospective studies with Arthroscopy as Gold Standard as diagnostic reference (Table 1).

Among these studies we found 22 that analyzed the correlation between imaging studies and arthroscopy (Se. \& Sp.) in both menisci [35-56] and one paper in a single meniscus [18]. About the correlation between imagenology and arthroscopy in ACL we found 13 papers, [35-37,39,41-43,46-48,52,54,55] and 8 studies regarding the correlation between clinical examination and arthroscopy in meniscal injuries [18,35,43-46,52,53].

We found one work that compared the intensity of the MRI scanner's field (1.5 T vs. $3 \mathrm{~T}$ ) for the assessment of meniscal and ligamentary disorders in the knee [47]. There were three studies that compared the diagnostic power of different sequences of the MRI scanner for meniscal injuries $[38,51,55]$.

Finally, we found three papers that compared ultrasonography with MRI for the detection of meniscal injuries $[18,50,56]$.

Regarding the description of the studies, we found the following: a) $14[35,36,39,40,43-48,51-53,55]$ that showed a higher level of sensitivity than specificity in the medial meniscus and a higher level of specificity than sensitivity in the lateral meniscus; b) five $[37,38,41,54,56]$ that showed a higher level of specificity than of 
sensitivity in the medial and lateral menisci; c) two [42,49] that showed a higher level of specificity than sensitivity in the medial meniscus and a higher level of sensitivity than specificity in the lateral meniscus (it is relevant to highlight that low-intensity scanners were used in said works); d) one [18] showing a higher level of specificity than sensitivity in the medial meniscus in acute and chronic injuries; and finally e) one study[50] that showed a higher level of sensitivity than of specificity globally in both menisci.

\section{IS \\ PRISMA 2009 Flow Diagram}
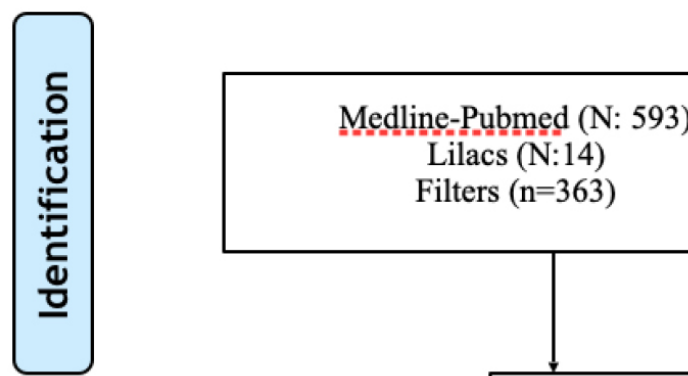

Lilacs (N:14)

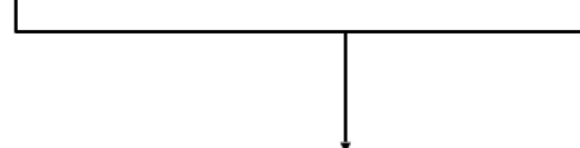

Adicional articles identified in other series $(n=6)$

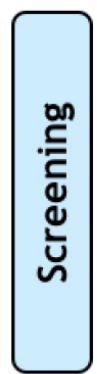

Articles after elimination of the repeated ones

$(\mathrm{n}=368)$
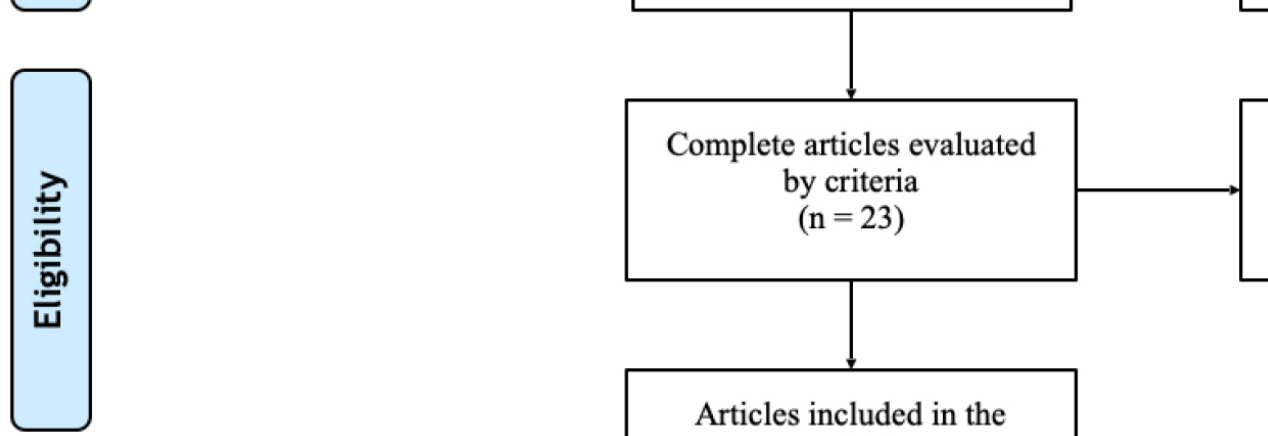

Complete articles excluded by criteria $(\mathrm{n}=0)$

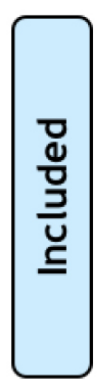

Articles included in the analysis $(\mathrm{n}=23)$

Figure 1. Systematic Review Flowchart, PRISMA Protocol, 2009. 
Table 1.

\begin{tabular}{|c|c|c|c|c|c|c|c|c|c|}
\hline & Author & Year & Hospital & $\begin{array}{l}\text { Type of } \\
\text { study }\end{array}$ & $\mathbf{N}$ & $\begin{array}{c}\text { Age } \\
\text { (years) }\end{array}$ & Period & $\begin{array}{l}1 \text { or both } \\
\text { menisci }\end{array}$ & $\begin{array}{l}\text { Sensitivity and Specificity } \\
\text { (\%) - MI: internal menisci, } \\
\text { ME: external menisci }\end{array}$ \\
\hline 1 & Muresan et al & 2017 & $\begin{array}{l}\text { University of Medicine and } \\
\text { Pharmacy of Tîrgu Mureş, } \\
\text { Tîrgu Mureş, România }\end{array}$ & Prospective & 45 & 29,4 & $\begin{array}{l}\text { May } 2014 \\
\text { - July } 2015\end{array}$ & $\begin{array}{l}\text { Both } \\
\text { menisci }\end{array}$ & $+\underset{75,0 / 80,0}{\text { S y E: MI: 69,4/76,6 ME: }}$ \\
\hline 2 & Chagas-Neto et al & 2016 & $\begin{array}{l}\text { Division of Radiology, } \\
\text { Internal Medicine Department, } \\
\text { Faculdade de Medicina } \\
\text { de Ribeirão Preto da } \\
\text { Universidade de São Paulo } \\
\text { (FMRPUSP), } \\
\text { Ribeirão Preto, SP, Brazil }\end{array}$ & Prospective & 38 & 33,5 & - & $\begin{array}{l}\text { Both } \\
\text { menisci }\end{array}$ & + $\underline{\text { S y E }: ~ M I: ~ 83 / 71 ~ M E: ~ 54 / 92 ~}$ \\
\hline 3 & $\begin{array}{l}\text { Nilton Orlando } \\
\text { Júnior et al }\end{array}$ & 2015 & $\begin{array}{l}\text { Fundacão Hospital Adriano } \\
\text { Jorge, Manaus, AM, Brazil }\end{array}$ & Prospective & 72 & 33,54 & $\begin{array}{l}\text { June } 2012- \\
\text { December } \\
2013\end{array}$ & $\begin{array}{l}\text { Both } \\
\text { menisci }\end{array}$ & $+\underset{65 / 88,46}{\text { S y E: MI: 92,50/74,19 ME: }}$ \\
\hline 4 & Khan et al & 2015 & $\begin{array}{l}\text { Department of Orthopedics } \\
\text { of the Holy Family Hospital, } \\
\text { New Delhi, India }\end{array}$ & Prospective & 26 & $13-50$ & $\begin{array}{l}\text { March } \\
\text { 2011- May } \\
2012\end{array}$ & $\begin{array}{l}\text { Both } \\
\text { menisci }\end{array}$ & $+\underset{50 / 86}{\text { S y E: MI: } 100 / 50 \text { ME: }}$ \\
\hline 5 & $\begin{array}{c}\text { James L. Cook } \\
\text { et al }\end{array}$ & 2014 & $\begin{array}{l}\text { Missouri Orthopaedic } \\
\text { Institute, Department of } \\
\text { Orthopaedic Surgery, } \\
\text { University of Missouri. }\end{array}$ & Prospective & 71 & 37.2 & - & $\begin{array}{l}\text { Both } \\
\text { menisci }\end{array}$ & $+\underline{\text { S y E }: 91,7 / 66,7}$ \\
\hline 6 & H.N Chen et al & 2014 & $\begin{array}{l}\text { The Second Affiliated } \\
\text { Hospital of Soochow } \\
\text { University, China. }\end{array}$ & Prospective & 171 & 45.8 & $\begin{array}{l}\text { October } \\
2009- \\
\text { December } \\
2011\end{array}$ & $\begin{array}{l}\text { Both } \\
\text { menisci }\end{array}$ & 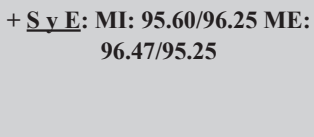 \\
\hline 7 & Wei Chen et al & 2014 & $\begin{array}{l}\text { Department of Radiology, } \\
\text { Southwest Hospital, The Third } \\
\text { Military Medical University, } \\
\text { Chongqing 400038, China }\end{array}$ & Prospective & 94 & 40,5 & $\begin{array}{l}\text { December } \\
2011 \text { - } \\
\text { October } \\
2012\end{array}$ & $\begin{array}{l}\text { Both } \\
\text { menisci }\end{array}$ & $+\underline{S}^{\text {S E E }}:$ MI: $93,5 / 66,7$ ME: \\
\hline 8 & Bari et al & 2014 & $\begin{array}{c}\text { Department of } \\
\text { Radiodiagnosis, JNMC, } \\
\text { DMIMS, Sawangi (Meghe) } \\
\text { Wardha, Maharashtra, India }\end{array}$ & Prospective & 71 & - & $\begin{array}{l}\text { June } 2012 \\
\text { - July } 2014\end{array}$ & $\begin{array}{l}\text { Both } \\
\text { menisci }\end{array}$ & $+\underset{\text { S v E: MI: } 93,54 / 87,50 \mathrm{ME}:}{77,77 / 81,81}$ \\
\hline 9 & $\begin{array}{l}\text { Timotijevic } \\
\text { Sladjan et al }\end{array}$ & 2014 & Hospital - KBC & Prospective & 107 & 29.7 & $* * * *$ & $\begin{array}{l}\text { External } \\
\text { menisci }\end{array}$ & $+\underset{75 / 95 \text { (cronic) }}{+ \text { y E }: 68 / 87 \text { (acute) S E }:}$ \\
\hline 10 & Navali et al & 2013 & $\begin{array}{l}\text { The Orthopedic Ward at Tabriz } \\
\text { Shohada Hospital,Tabriz, Iran }\end{array}$ & Prospective & 120 & 29,13 & $\begin{array}{l}\text { October } \\
2008- \\
\text { October } \\
2009\end{array}$ & $\begin{array}{l}\text { Both } \\
\text { menisci }\end{array}$ & $+\underline{\text { S v E: }}$ MI: $84,2 / 71.4$ ME: \\
\hline 11 & $\begin{array}{l}\text { Roza Dzoleva- } \\
\text { Tolevska et al }\end{array}$ & 2013 & $\begin{array}{c}\text { University Orthopaedic } \\
\text { Surgery Clinic, Ss. Cyril and } \\
\text { Methodius University, Skopje, } \\
\text { R. Macedonia }\end{array}$ & Prospective & 70 & - & - & $\begin{array}{l}\text { Both } \\
\text { menisci }\end{array}$ & $+\underset{40 / 92,7}{\text { S y E: }}$ MI: $79,5 / 38,1$ ME: \\
\hline 12 & Sharifah et al & 2013 & $\begin{array}{c}\text { Department of Radiology, } \\
\text { University Kebangsaan } \\
\text { Malaysia, } \\
\text { Kuala Lumpur, Malaysia }\end{array}$ & Prospective & 65 & 28 & $\begin{array}{c}2009- \\
2012\end{array}$ & $\begin{array}{l}\text { Both } \\
\text { menisci }\end{array}$ & 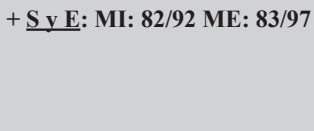 \\
\hline 13 & $\begin{array}{l}\text { Pieter Van Dyck } \\
\text { et al }\end{array}$ & 2013 & $\begin{array}{l}\text { University Hospital and } \\
\text { the University of Antwerp, } \\
\text { Antwerp (Edegem), Belgium }\end{array}$ & Prospective & 200 & 45 & $\begin{array}{c}2010- \\
2012\end{array}$ & $\begin{array}{l}\text { Both } \\
\text { menisci }\end{array}$ & $\begin{array}{c}+\underline{\text { S v E : MI: } 93 / 90 \text { ME: } 77 / 99} \\
\text { (1,5 T) MI: 96/88 ME: 82/98 } \\
\text { (3 T) }\end{array}$ \\
\hline 14 & Ersin Eercin et al & 2011 & $\begin{array}{c}\text { Ankara Mevki Military } \\
\text { Hospital,Orthopedics and } \\
\text { Traumatology } \\
\text { Clinic,Istanbul, Turkey }\end{array}$ & Prospective & 30 & 38 & 5 months & $\begin{array}{l}\text { Both } \\
\text { menisci }\end{array}$ & + $\underline{\text { S v E }}:$ MI: $95 / 60$ ME: $67 / 88$ \\
\hline 15 & F. Rayan et al & 2009 & Kettering General hospital & Prospective & 131 & - & 36 months & $\begin{array}{l}\text { Both } \\
\text { menisci }\end{array}$ & + $\underline{\text { S v E }}:$ MI: $76 / 52$ ME: $61 / 92$ \\
\hline
\end{tabular}




\begin{tabular}{|c|c|c|c|c|c|c|c|c|c|}
\hline & Author & Year & Hospital & $\begin{array}{l}\text { Type of } \\
\text { study }\end{array}$ & $\mathbf{N}$ & $\begin{array}{c}\text { Age } \\
\text { (years) }\end{array}$ & Period & $\begin{array}{c}1 \text { or both } \\
\text { menisci }\end{array}$ & $\begin{array}{l}\text { Sensitivity and Specificity } \\
\text { (\%) - MI: internal menisci, } \\
\text { ME: external menisci }\end{array}$ \\
\hline 16 & $\begin{array}{l}\text { Gul-e-khanda } \\
\text { et al }\end{array}$ & 2008 & $\begin{array}{c}\text { Radiology Department, Aga } \\
\text { Khan University Hospital, } \\
\text { Karachi }\end{array}$ & Prospective & 50 & - & 2006-2007 & $\begin{array}{l}\text { Both } \\
\text { menisci }\end{array}$ & $+\underline{\text { S v E: MI: } 100 / 69.27 \text { ME: }}$ \\
\hline 17 & $\begin{array}{l}\text { M.J. Sampson } \\
\text { et al }\end{array}$ & 2008 & $\begin{array}{l}\text { Departments of Radiology and } \\
\text { Orthopaedics, Sports Surgery } \\
\text { Clinic, Santry Demesne, } \\
\text { Dublin. }\end{array}$ & Prospective & 61 & 29,6 & - & $\begin{array}{l}\text { Both } \\
\text { menisci }\end{array}$ & + $\underline{\text { S v E: }}$ MI: 91/93 ME: $77 / 93$ \\
\hline 18 & Naranje et al & 2008 & $\begin{array}{c}\text { Departments of } \\
\text { OrthopaedicsAll India } \\
\text { Institute of Medical Sciences, } \\
\text { New } \\
\text { Delhi, India }\end{array}$ & Prospective & 50 & 27 & - & $\begin{array}{l}\text { Both } \\
\text { menisci }\end{array}$ & + S y E: MI: 96/89 ME: $84 / 90$ \\
\hline 19 & $\begin{array}{c}\text { Noha H. Behairy } \\
\text { et al }\end{array}$ & 2008 & Cairo University, Cairo, Egypt & Prospective & 70 & $22-59$ & - & $\begin{array}{l}\text { Both } \\
\text { menisci }\end{array}$ & 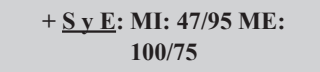 \\
\hline 20 & $\begin{array}{l}\text { F.K.W Schafer } \\
\text { et al }\end{array}$ & 2006 & $\begin{array}{l}\text { Department of Diagnostic } \\
\text { Radiology, Christian- } \\
\text { Albrechts- } \\
\text { Universitaet Kiel, Kiel, } \\
\text { Germany }\end{array}$ & Prospective & 31 & 40.5 & 18 months & $\begin{array}{l}\text { Both } \\
\text { menisci }\end{array}$ & $+\underset{\text { S y E: MI: } 88,6 / 98,3 \text { ME: }}{90 / 95,9}$ \\
\hline 21 & $\begin{array}{l}\text { Keith Winters } \\
\quad \text { et al }\end{array}$ & 2005 & Wellington Public Hospital & Prospective & 67 & 37 & $1999-2003$ & $\begin{array}{l}\text { Both } \\
\text { menisci }\end{array}$ & 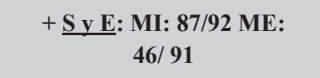 \\
\hline 22 & Sanchez Vaz et al & 2005 & $\begin{array}{c}\text { Orthopaedics and } \\
\text { Traumatology Department, } \\
\text { Hospital Regional do Paraná, } \\
\text { State University of Londrina - } \\
\text { Londrina/PA, Brazil. }\end{array}$ & Prospective & 300 & - & $\begin{array}{l}\text { August } \\
1998- \\
\text { March } \\
2002\end{array}$ & $\begin{array}{l}\text { Both } \\
\text { menisci }\end{array}$ & 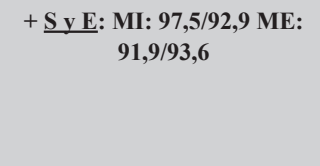 \\
\hline 23 & Kocabey et al & 2004 & $\begin{array}{l}\text { Division of Orthopedics } \\
\text { (D.L.J.), Section of Sports } \\
\text { Medicine (Y.K., W.M.I., } \\
\text { Ö.A.A.), University of } \\
\text { Kentucky, Lexington, } \\
\text { Kentucky, U.S.A }\end{array}$ & Prospective & 50 & 22 & $\begin{array}{l}\text { August } \\
2001- \\
\text { December } \\
2001\end{array}$ & $\begin{array}{c}\text { Both } \\
\text { menisci }\end{array}$ & + $\underline{\text { S y E: }}$ MI: 80/79 ME: 85/97 \\
\hline
\end{tabular}

\section{Discussion}

The results of our review are shown within the context of other two previous reviews related to meniscal injuries $[29,57]$. Unlike the previous reviews, our investigation only included prospective studies with the aim of finding the most accurate results.

It is worth highlighting that, even though it is not the main focus of our work, the clinical examination is of utmost relevance with regards to the diagnosis of meniscal injuries. Several studies show that a correct and thorough clinical examination, preferably performed by an expert surgeon, is more sensitive and specific than MRI in order to diagnose medial meniscus injuries but has similar results in lateral meniscus issues $[8,43-45,58]$.

Conceptually, it is customary to request an MRI in the event of diagnostic doubts $[35,43,46,52]$ or when another therapeutic procedure is to be performed, e. g.: anterior cruciate ligament (ACL) surgery $[42,45,59]$.

Another diagnostic element with good results, comparable with MRI, is ultrasonography [50,56]. Cook et al. state that in their series they found the same level of sensitivity but a better level of specificity than MRI for the diagnosis of meniscal injuries, thusly encouraging its usage, firstly due to its efficacy and secondly due to its low cost and quickness regarding the performance logistics [50].

Focusing on MRI, there are studies that substantially support its usage for diagnosing injuries within the context of a traumatic knee and, specifically, for meniscal injuries $[60,61]$. The vast majority of the studies analyzed in this review affirm that this test has great potential in comparison with other diagnostic tools (such as the clinical examination or the ultrasonography). They show that MRI has a better sensitivity level for the medial meniscus and a better specificity level for the lateral meniscus $[35,36,39,40,43-48,51-53,55]$, and, also as previously stated, we compared similar results with other reviews contemporary to ours. ${ }^{29,57)}$ There were studies in our review that did not show what most of the bibliography affirms [38,42,49]. Some, such as the one published by Behairy et al., showed opposite results: a higher sensitivity level for the lateral meniscus and a higher specificity level for the medial meniscus. Said authors say that this result might be the consequence of including anterior cruciate ligament injuries, which would decrease the sensitivity of the medial meniscus [11].

Other authors like Magee et. al., said that the MRI scanner's power might be another element that modifies results [62]. The magnetic field's intensity is a commonly reported study variable that might have 
some impact over the precision in meniscal injury cases. However, after analyzing different studies, we found no significant difference among different magnetic fields' intensities, higher or lower $(3.0 \mathrm{~T}$ and $1.5 \mathrm{~T})[18,41,47,63]$. Moreover, there are descriptions stating that $0.2 \mathrm{~T}$ scanners are equally effective and have lower costs than the conventional ones used nowadays $[64,65]$. Furthermore, given the current technological progress, it is necessary to develop new studies.

Some authors limited their revisions to the most current studies; they wanted to use those with modern technology and more experienced imagenology specialists [29]. This isn't the case of other authors who disagree with the aforesaid, who claim that the previous studies have a higher quality and better methodology and that there might be a selection mistake [57]. In other words, all studies should be included regardless of its publishing year. This also avoids the bias that may happen when authors select a specific year for exclusion.

From the analysis of the collected information, and as a consequence of the preceding discussion, we may consider that there is no consistency of results and opinions in English-published bibliography of a prospective profile. Nevertheless, we must acknowledge that the prevailing results are those that prioritize the relevance of MRI in terms of sensitivity and specificity. We must currently accept that MRI is a very costly study for diagnosing meniscal injuries. There are some variations in its sensitivity and specificity, but they are minor and, therefore, do not invalidate these conclusions. There is no doubt that, in future years, technological progress shall provide more accurate devices that will allow us to reach safer diagnostic levels.

Likewise we shouldn't forget that clinical examination, when combined with MRI, offers the most accurate non-invasive method to obtain the available information about meniscal pathological findings $[53,66]$.

A thorough search throughout medical literature, including PubMed and Lilacs databases, provided us with 23 studies that informed about the correlation between imaging screening and arthroscopy in both menisci and only one work about the lateral meniscus, all of them published between 2004 and 2018, and they constitute the strength of our study. The limitations are the reduced amount of cases in some studies and the inability of access to final conclusions due to the lack of uniformity in the results of the analyzed studies.

\section{References}

1. Clayton RA, Court-Brown CM (2008) The epidemiology of musculoskeletal tendinous and ligamentous injuries. Injury 39: 1338-1344. [crossref]

2. McCarty EC, Marx RG, DeHaven KE (2002) Meniscus repair: considerations in treatment and update of clinical results. Clin Orthop Relat Res122-134. [crossref]

3. Getgood A, Robertson A (2010) (v) Meniscal tears, repairs and replacement - a current concepts review. Orthopaedics and Trauma. 24: 121-128.

4. Stoller D (2016) Stoller's Orthopaedics and Sports Medicine: The Knee: $L W W$ $129-133$.

5. Majewski M, Susanne H, Klaus S (2006) Epidemiology of athletic knee injuries: A 10-year study. Knee 13: 184-188. [crossref]

6. Gillies H, Seligson D (1979) Precision in the diagnosis of meniscal lesions: a comparison of clinical evaluation, arthrography, and arthroscopy. J Bone Joint Surg Am 61: 343-346.

7. Miller GK (1996) A prospective study comparing the accuracy of the clinical diagnosis of meniscus tear with magnetic resonance imaging and its effect on clinical outcome. Arthroscopy 12: 406-413.
8. Rose NE, Gold SM (1996) A comparison of accuracy between clinical examination and magnetic resonance imaging in the diagnosis of meniscal and anterior cruciate ligament tears. Arthroscopy 12: 398-405.

9. Karachalios T, Hantes M, Zibis AH, Zachos V, Karantanas AH, et al. (2005) Diagnostic accuracy of a new clinical test (the Thessaly test) for early detection of meniscal tears. J Bone Joint Surg Am 87: 955-962. [crossref]

10. Harrison BK, Abell BE, Gibson TW (2009) The Thessaly test for detection of meniscal tears: validation of a new physical examination technique for primary care medicine. Clin J Sport Med 19: 9-12.

11. De Smet AA, Graf BK (1994) Meniscal tears missed on MR imaging: relationship to meniscal tear patterns and anterior cruciate ligament tears. AJR Am J Roentgenol 162: 905-911. [crossref]

12. Shelbourne KD, Martini DJ, McCarroll JR, VanMeter CD (1995) Correlation of joint line tenderness and meniscal lesions in patients with acute anterior cruciate ligament tears. Am J Sports Med 23: 166-169.

13. Jee WH, McCauley TR, Kim JM (2004) Magnetic resonance diagnosis of meniscal tears in patients with acute anterior cruciate ligament tears. J Comput Assist Tomogr 28: $402-406$.

14. Mather RC 3rd, Garrett WE, Cole BJ, Hussey K, Bolognesi MP, et al. (2015) Costeffectiveness analysis of the diagnosis of meniscus tears. Am J Sports Med 43: 128-137. [crossref]

15. Mackenzie R, Dixon AK, Keene GS, Hollingworth W, Lomas DJ, et al. (1996) Magnetic resonance imaging of the knee: assessment of effectiveness. Clin Radiol 51: 245-250. [crossref]

16. Helms CA (2002) The meniscus: recent advances in MR imaging of the knee. AJR Am J Roentgenol 179: 1115-1122. [crossref]

17. Major NM, Beard LN Jr, Helms CA (2003) Accuracy of MR imaging of the knee in adolescents. AJR Am J Roentgenol 180: 17-19. [crossref]

18. Timotijevic S, Vukasinovic Z, Bascarevic Z (2014) Correlation of clinical examination, ultrasound sonography, and magnetic resonance imaging findings with arthroscopic findings in relation to acute and chronic lateral meniscus injuries. J Orthop Sci 19: 71-76.

19. Brooks S, Morgan M (2002) Accuracy of clinical diagnosis in knee arthroscopy. Ann $R$ Coll Surg Engl 84: 265-268. [crossref]

20. Harper KW, Helms CA, Lambert HS 3rd, Higgins LD (2005) Radial meniscal tears: significance, incidence, and MR appearance. AJR Am J Roentgenol 185: $1429-1434$.

21. Kornaat PR, Bloem JL, Ceulemans RY, Riyazi N, Rosendaal FR, et al. (2006) Osteoarthritis of the knee: association between clinical features and MR imaging findings. Radiology 239: 811-817.

22. Laoruengthana A, Jarusriwanna A (2012) Sensitivity and specificity of magnetic resonance imaging for knee injury and clinical application for the Naresuan University Hospital. J Med Assoc Thai 95: 151-157.

23. Crues JV, 3rd, Mink J, Levy TL, Lotysch M, Stoller DW (1987) Meniscal tears of the knee: accuracy of MR imaging. Radiology 164: 445-448.

24. Fischer SP, Fox JM, Del Pizzo W, Friedman MJ, Snyder SJ, et al. (1991) Accuracy of diagnoses from magnetic resonance imaging of the knee. A multi-center analysis of one thousand and fourteen patients. J Bone Joint Surg Am 73: 2-10. [crossref]

25. Quinn SF, Brown TR, Szumowski J (1992) Menisci of the knee: radial MR imaging correlated with arthroscopy in 259 patients. Radiology 185: 577-580. [crossref]

26. Justice WW, Quinn SF (1995) Error patterns in the MR imaging evaluation of menisci of the knee. Radiology 196: 617-621. [crossref]

27. Feller JA, Webster KE (2001) Clinical value of magnetic resonance imaging of the knee. ANZ J Surg 71: 534-537. [crossref]

28. McNally EG (2002) Magnetic resonance imaging of the knee. BMJ 325: 115-116. [crossref]

29. Oei EH, Nikken JJ, Verstijnen AC, Ginai AZ, Myriam Hunink MG (2003) MR imaging of the menisci and cruciate ligaments: a systematic review. Radiology 226 : 837-848. [crossref]

30. Chang CY1, Wu HT, Huang TF, Ma HL, Hung SC (2004) Imaging evaluation of meniscal injury of the knee joint: a comparative MR imaging and arthroscopic study. Clin Imaging 28: 372-376. [crossref]

31. Ruwe PA, Wright J, Randall RL, Lynch JK, Jokl P, et al. (1992) Can MR imaging effectively replace diagnostic arthroscopy? Radiology 183: 335-339. [crossref]

32. Bridgman S, Richards PJ, Walley G, MacKenzie G, Clement D, et al. (2007) The effect of magnetic resonance imaging scans on knee arthroscopy: randomized controlled trial. Arthroscopy 23: 1167-1173 e1.

33. Phelan N, Rowland P, Galvin R, O'Byrne JM (2016) A systematic review and metaanalysis of the diagnostic accuracy of MRI for suspected ACL and meniscal tears of the knee. Knee Surg Sports Traumatol Arthrosc. 24: 1525-1539.

34. De Smet AA (2012) How I diagnose meniscal tears on knee MRI. AJR Am J Roentgenol 199: 481-499. [crossref] 
35. Kocabey Y, Tetik O, Isbell WM, Atay OA, Johnson DL (2004) The value of clinical examination versus magnetic resonance imaging in the diagnosis of meniscal tears and anterior cruciate ligament rupture. Arthroscopy 20: 696-700.

36. Vaz CE, Camargo OP, Santana PJ, Valezi AC (2005) Accuracy of magnetic resonance in identifying traumatic intraarticular knee lesions. Clinics (Sao Paulo) 60: $445-450$.

37. Winters K, Tregonning R (2005) Reliability of magnetic resonance imaging of the traumatic knee as determined by arthroscopy. $N Z$ Med $J$ 118: U1301. [crossref]

38. Schafer FK, Schafer PJ, Brossmann J, Frahm C, Hilgert RE, Heller M, et al. (2006) Value of fat-suppressed proton-density-weighted turbo spin-echo sequences in detecting meniscal lesions: comparison with arthroscopy. Acta Radiol 47: 385-390.

39. Khanda GE, Akhtar W, Ahsan H, Ahmad N (2008) Assessment of menisci and ligamentous injuries of the knee on magnetic resonance imaging: correlation with arthroscopy. J Pak Med Assoc 58: 537-540. [crossref]

40. Naranje S, Mittal R, Nag H, Sharma R (2008) Arthroscopic and magnetic resonance imaging evaluation of meniscus lesions in the chronic anterior cruciate ligamentdeficient knee. Arthroscopy 24: 1045-1051.

41. Sampson MJ, Jackson MP, Moran CJ, Shine S, Moran R, et al. (2008) Three Tesla MRI for the diagnosis of meniscal and anterior cruciate ligament pathology: a comparison to arthroscopic findings. Clin Radiol 63: 1106-1111.

42. Behairy NH, Dorgham MA, Khaled SA (2009) Accuracy of routine magnetic resonance imaging in meniscal and ligamentous injuries of the knee: comparison with arthroscopy. Int Orthop 33: 961-967. [crossref]

43. Rayan F, Bhonsle S, Shukla DD (2009) Clinical, MRI, and arthroscopic correlation in meniscal and anterior cruciate ligament injuries. Int Orthop 33: 129-132. [crossref]

44. Ercin E, Kaya I, Sungur I, Demirbas E, Ugras AA, Cetinus EM (2012) History, clinical findings, magnetic resonance imaging, and arthroscopic correlation in meniscal lesions. Knee Surg Sports Traumatol Arthrosc 20: 851-856.

45. Dzoleva-Tolevska R, Poposka A, Samardziski M, Georgieva D (2013) Comparative analysis of diagnostic methods in meniscal lesions. Pril (Makedon Akad Nauk Umet Odd Med Nauki) 34: 79-83.

46. Navali AM, Bazavar M, Mohseni MA, Safari B, Tabrizi A (2013) Arthroscopic evaluation of the accuracy of clinical examination versus MRI in diagnosing meniscus tears and cruciate ligament ruptures. Arch Iran Med 16: 229-232.

47. Van Dyck P, Vanhoenacker FM, Lambrecht V, Wouters K, Gielen JL, et al. (2013) Prospective comparison of 1.5 and 3.0-T MRI for evaluating the knee menisci and ACL. J Bone Joint Surg Am 95: 916-924. [crossref]

48. Bari AA, Kashikar SV, Lakhkar BN, Ahsan MS (2014) Evaluation of MRI versus arthroscopy in anterior cruciate ligament and meniscal injuries. $J$ Clin Diagn Res 8: RC14-18.

49. Chen HN, Dong QR, Wang Y (2014) Accuracy of low-field MRI on meniscal tears. Genet Mol Res 13: 4267-4271. [crossref]

50. Cook JL, Cook CR, Stannard JP, Vaughn G, Wilson N, et al. (2014) MRI versus ultrasonography to assess meniscal abnormalities in acute knees. J Knee Surg 27: 319-324.

51. Chen W, Zhao J, Wen Y, Xie B, Zhou X, et al. (2015) Accuracy of 3-T MRI using susceptibility-weighted imaging to detect meniscal tears of the knee. Knee Surg Sports Traumatol Arthrosc 23: 198-204.
52. Khan HA, Ahad H, Sharma P, Bajaj P, Hassan N, Kamal Y (2015) Correlation between magnetic resonance imaging and arthroscopic findings in the knee joint. Trauma Mon 20: 18635.

53. Orlando Junior N, de Souza Leao MG, de Oliveira NH (2015) Diagnosis of knee injuries: comparison of the physical examination and magnetic resonance imaging with the findings from arthroscopy. Rev Bras Ortop 50: 712-9.

54. Sharifah MI, Lee CL, Suraya A, Johan A, Syed AF, Tan SP (2015) Accuracy of MRI in the diagnosis of meniscal tears in patients with chronic ACL tears. Knee Surg Sports Traumatol Arthrosc 23: 826-30.

55. Chagas-Neto FA, Nogueira-Barbosa MH, Lorenzato MM, Salim R, Kfuri-Junior M, Crema MD (2016) Diagnostic performance of 3D TSE MRI versus 2D TSE MRI of the knee at $1.5 \mathrm{~T}$, with prompt arthroscopic correlation, in the detection of meniscal and cruciate ligament tears. Radiol Bras 49: 69-74.

56. Muresan S, Muresan M, Voidazan S, Neagoe R (2017) The accuracy of musculoskeletal ultrasound examination for the exploration of meniscus injuries in athletes. J Sports Med Phys Fitness 57: 589-94.

57. Crawford R, Walley G, Bridgman S, Maffulli N (2007) Magnetic resonance imaging versus arthroscopy in the diagnosis of knee pathology, concentrating on meniscal lesions and ACL tears: a systematic review. Br Med Bull 84: 5-23.

58. Hardy JC, Evangelista GT, Grana WA, Hunter RE (2012) Accuracy of magnetic resonance imaging of the knee in the community setting. Sports Health 4: 222-31.

59. Ali M, Jackson T, Rayan GM (2009) Closing wedge osteotomy of abnormal middle phalanx for clinodactyly. J Hand Surg Am 34: 914-918. [crossref]

60. Cellã ir R, Sokol D, Lacko M, Å tolfa $\AA$, Gharaibeh A, et al. (2012) [Magnetic resonance imaging in the diagnosis of intra-articular lesions of the knee]. Acta Chir Orthop Traumatol Cech 79: 249-254. [crossref]

61. Dutka J, Skowronek M, Skowronek P, Dutka L (2012) Arthroscopic verification of objectivity of the orthopaedic examination and magnetic resonance imaging in intra-articular knee injury. Retrospective study. Wideochir Inne Tech Maloinwazyjne 7: $13-8$.

62. Magee T1, Williams D (2006) 3.0-T MRI of meniscal tears. AJR Am J Roentgenol 187: 371-375. [crossref]

63. Grossman JW, De Smet AA, Shinki K (2009) Comparison of the accuracy rates of 3-T and 1.5-T MRI of the knee in the diagnosis of meniscal tear. AJR Am J Roentgenol 193: 509-514. [crossref]

64. Kersting-Sommerhoff B, Gerhardt P, Golder W, Hof N, Riel KA, Helmberger H, et al. (1995) [MRI of the knee joint: first results of a comparison of 0,2-T specialized system and 1,5-T high field strength magnet]. Rofo 162: 390-5.

65. Böttcher P, Brühschwein A, Winkels P, Werner H, Ludewig E, et al. (2010) Value of low-field magnetic resonance imaging in diagnosing meniscal tears in the canine stifle: a prospective study evaluating sensitivity and specificity in naturally occurring cranial cruciate ligament deficiency with arthroscopy as the gold standard. Vet Surg 39: 296-305. [crossref]

66. Glashow JL, Katz R, Schneider M, Scott WN (1989) Double-blind assessment of the value of magnetic resonance imaging in the diagnosis of anterior cruciate and meniscal lesions. J Bone Joint Surg Am 71: 113-9.

Citation:

Gelink A, Casales N, Macadar N, Francescoli L (2019) Correlation between Magnetic Resonance Imaging and Arthroscopy in Meniscal Injuries. Integr J Orthop Traumatol Volume 2 (4): 1-7. 